\title{
Allelopathic Potential of Sunflower Extract on Weed Control and Wheat Yield Under Subtropical Conditions
}

\author{
Hasib Bin Saif ${ }^{1}$, Md. Nasimul Bari ${ }^{1}$, Md. Rafiqul Islam ${ }^{1, ~ *, ~ M d . ~ A b i a r ~ R a h m a n ~}{ }^{2}$ \\ ${ }^{1}$ Department of Agronomy, Bangabandhu Sheikh Mujibur Rahman Agricultural University, Gazipur, Bangladesh \\ ${ }^{2}$ Department of Agroforestry and Environment, Bangabandhu Sheikh Mujibur Rahman Agricultural University, Gazipur, Bangladesh
}

Email address:

rafiarib@yahoo.com (M. R. Islam)

${ }^{*}$ Corresponding author

\section{To cite this article:}

Hasib Bin Saif, Md. Nasimul Bari, Md. Rafiqul Islam, Md. Abiar Rahman. Allelopathic Potential of Sunflower Extract on Weed Control and Wheat Yield Under Subtropical Conditions. International Journal of Applied Agricultural Sciences. Vol. 2, No. 4, 2016, pp. 44-48. doi: 10.11648/j.ijaas.20160204.11

Received: April 12, 2016; Accepted: June 3, 2016; Published: June 17, 2016

\begin{abstract}
A field experiment was conducted to evaluate the effect of sunflower plant extract on weed control and productivity of wheat. Dried and fresh sunflower plant extracts (SPE) were applied @ $5 \mathrm{t} \mathrm{ha}^{-1}$ and $10 \mathrm{tha}^{-1}$ at pre- and post-emergence of weeds in wheat plots. In addition, weed free, manual weeding and unweeded control treatments were also imposed in the experiment. Application of fresh SPE @ $10 \mathrm{t} \mathrm{ha}^{-1}$ at post-emergence contributed to the highest weed control efficiency, next to manual weed control treatment throughout the crop growing period. This treatment showed the highest weed control efficiency of $49.71 \%$ and $53.41 \%$ at 45 and 60 days after sowing, respectively. Application of fresh SPE @ $5 \mathrm{t} \mathrm{ha}^{-1}$ at post-emergence was found to be beneficial on the growth and development of wheat compared to other treatments. Apart from weed free and unweeded situations, the highest grain yield of $3.91 \mathrm{t} \mathrm{ha}^{-1}$ was recorded in the treatment receiving fresh SPE @ $5 \mathrm{tha}^{-1}$ applied at post-emergence. The study further suggested that the application of fresh sunflower plant extract @ 5 ha $^{-1}$ during post-emergence might be considered as a viable alternative to traditional weed management practices under subtropical environment.
\end{abstract}

Keywords: Allelopathy, Sunflower Extract, Weed Control, Wheat Yield, Subtropical Climate

\section{Introduction}

Wheat (Triticum aestivum, L) is second to rice among cereals in production and consumption importance in Bangla$\operatorname{desh}[1,2]$. However, yield of wheat in Bangladesh is very low compared to other wheat growing countries. Surprisingly wheat production is predicted to fall by $32 \%$ as early as 2050 in Bangladesh [3]. Weed infestation is considered as a major menace of wheat productivity. Weed is also a serious constraint of wheat production in the tropical and subtropical regions of the world. Its infestation might decrease $20-60 \%$ of grain yield in wheat [4-6]. In many Asian countries, hand weeding is traditionally practiced to control weeds in wheat field, but scarcity of laborers and increased labor wages have been forcing wheat growers to switch from traditional to chemical weed control. Considering the extensive use of herbicides in recent decade, allelopathic weed control has been gaining popularity worldwide as an alternative to chemical control of weed [7] and to combat the evolution of herbicide resistance in weeds [8]. In allelopathic weed management, plants having allelopathic potential are successfully utilized for controlling weeds [9]. Allelopathy is now regarded as a novel approach to keep the environment safe and to develop sustainable agriculture [10].

Sunflower has been reported as a potent allelopathic plant having allelopathic chemicals such as sesquiterpene, lactones and terpenes from crude leaf extract that adversely effects other plants particularly upland agricultural weeds [8, 11 12]. Results from earlier studies showed that allelopathic chemicals of sunflower effectively control common broad- and narrow- leaf weeds in wheat $[13,14]$. Sunflower is an important oilseed crop in Bangladesh and the expansion of cultivation of the crop is possible due to its widespread adaptability. However, allelopathic potential of sunflower under subtropical climatic condition of Bangladesh is not widely tried hitherto. Therefore, the study was undertaken to evaluate the efficacy of sunflower plant extracts for weed control in 
wheat field and its subsequent effects on the growth and yield performance of wheat.

\section{Materials and Methods}

The study was carried out at the experimental field of the Bangabandhu Sheikh Mujibur Rahman Agricultural University (BSMRAU), Gazipur during November, 2011 to March, 2012. The experimental site is located in Madhupur Tract under Agro-ecological zone 28 at geographic coordinate $24^{0}$ $05^{\prime} \mathrm{N}$ latitude and $90^{\circ} 16^{\prime} \mathrm{E}$ longitude with an elevation of 8.4 $\mathrm{m}$ above the mean sea level. The Allelopathic material tested in the study was sunflower (variety: BARI Surjomukhi-2). For making dry sunflower plant extract (SPE), plants were cut at ground level and dried at ambient temperature for 15 days. The dried materials were chopped into $2 \mathrm{~cm}$ pieces. To prepare dry plant extract chopped materials was soaked in water for 24 hours. In case of preparing fresh SPE, fresh sunflower plants were chopped into $2 \mathrm{~cm}$ pieces and soaked in water for 24 hours. The decanted materials were passed through cotton cloth to obtain water extract for use. Both dry and fresh SPE were applied in the respective treatment plots. In case of pre-emergence of weed, the SPE were applied at three days before weed emergence. In case of post-emergence of weed, the SPE were applied after one week of weed emergence in wheat plot. Eleven treatments were maintained in the experimental plots of $3 \times 2 \mathrm{~m}$ in a randomized complete block design with three replications. A weed free and control treatment were also maintained for comparing with other treatments. Dry and fresh SPE were applied @ 5 and $10 \mathrm{tha}^{-1}$ at both pre- and post-emergence of weed in wheat plots. The treatments were, $\mathrm{T}_{1}=$ Dry SPE @ $5 \mathrm{t} \mathrm{ha}^{-1}$ at pre-emergence, $\mathrm{T}_{2}=$ Dry SPE @ $10 \mathrm{t}$ $\mathrm{ha}^{-1}$ at pre-emergence, $\mathrm{T}_{3}=$ Fresh SPE $@ 5 \mathrm{t} \mathrm{ha}^{-1}$ at preemergence, $\mathrm{T}_{4}=$ Fresh SPE @ $10 \mathrm{t} \mathrm{ha}^{-1}$ at pre-emergence, $\mathrm{T}_{5}=$ Dry SPE@ @ $5 \mathrm{tha}^{-1}$ at post-emergence, $\mathrm{T}_{6}=$ Dry SPE @ $10 \mathrm{t}$ $\mathrm{ha}^{-1}$ at post-emergence, $\mathrm{T}_{7}=$ Fresh SPE @ $5 \mathrm{t} \mathrm{ha}^{-1}$ at post-emergence, $\mathrm{T}_{8}=$ Fresh SPE @ $10 \mathrm{t} \mathrm{ha}^{-1}$ at post-emergence, $\mathrm{T}_{9}=$ Manual Weeding, $\mathrm{T}_{10}=$ Weed Free, $\mathrm{T}_{11}=$ Control. Wheat seeds@120 kg ha ${ }^{-1}$ were sown in line and necessary intercultural operations were done in each plot to ensure normal growth of the crop. Weeding was done regularly in the weed free plot; two times in manual weeding plot one at 25 DAS and another at 45 DAS. Thinning was also done as required. Four irrigations were given at 20,45,65 and 85 DAS.

The crop was harvested when the plants attained full maturity. At maturity, ten plants were harvested from each plot to record data on yield components and the plants from an area of $2.4 \mathrm{~m}^{2}$ was harvested to record data on grain and straw yields. The harvested crops were threshed, cleaned, and dried weight and necessary data were collected on various crop characters. Number of filled grains and sterile spikelets were counted from each panicle. Weed control efficiency was calculated with the following formula developed by Sawant and Jadav [15]: Weed control efficiency, WCE $=\{(\mathrm{DMC}-\mathrm{DMT}) /$ $\mathrm{DMC}\} \times 100$, where, $\mathrm{DMC}=$ Weed dry matter in unweeded treatment and DMT $=$ Weed dry matter in weed control treatment. Leaf area index (LAI) was measured starting from
30 DAT at 15 days interval with Leaf Area Meter (Model AAM-7 Hayashi Denko Co. Tokyo, Japan). Leaf area index was then calculated by using the following formula i.e. $\mathrm{LAI}=$ Leaf area for 5 hills $\left(\mathrm{cm}^{2}\right) /$ land area occupied by 5 hills $\left(\mathrm{cm}^{2}\right)$. Analysis of variance was done following the experimental design with the help of the computer package Statistix 10. Later the means were separated through Least Significance Difference (LSD) test.

\section{Results and Discussion}

\subsection{Weed Control Efficiency as Affected by Sunflower Plant Extract}

Weed control efficiency (WCE) indicates the percentage of weed infestation in a specific weeded treatment in comparison to unweeded control. Manually weeded plots $\left(T_{9}\right)$ maintained the highest weed control efficiency throughout wheat growing period, being followed by $\mathrm{T}_{8}$ treatment, while the least was maintained by $\mathrm{T}_{1}$ treatment receiving dry SPE @ $5 \mathrm{t} \mathrm{ha}^{-1}$ at pre-emergence only above control treatment $\left(\mathrm{T}_{11}\right)$ (Table 1). At 60 DAS, when wheat plants approached towards reproductive growth stage, the highest WCE of $49.71 \%$ was contributed by the plots receiving fresh SPE @ $10 \mathrm{t} \mathrm{ha}^{-1}$ at post-emergence (T8), being closely followed by T7 treatment receiving fresh SPE @ $5 \mathrm{t} \mathrm{ha}^{-1}$ at post-emergence, and the lowest $(29.48 \%)$ was observed in the plots receiving dry SPE @ 5 tha-1 applied as pre-emergence (T1) only above unweeded (control) treatment (T11). This trend also continued till maturity of wheat plants. Data revealed that, the treatment receiving fresh SPE @ $10 \mathrm{t}$ $\mathrm{ha}^{-1}$ at post-emergence contributed to the best weed control efficiency only next to manual weeding $(72.62 \%)$. It might be mentioned that, the conventional methods like hand weeding, although effective to control weeds, involve high labor, time and cost [16]. From economic point of view, it might, therefore, be reasonably argued that application of fresh sunflower plant extract @ 10 t ha-1 at post-emergence could be a viable alternative to manual weeding practices.

Table 1. Weed control efficiency in wheat field as affected by sunflower plant extract.

\begin{tabular}{lllllll}
\hline \multirow{2}{*}{ Treatment } & \% Weed Control Efficiency & & & \\
\cline { 2 - 7 } & 30 DAS & 45 DAS & 60 DAS & 75 DAS & 90 DAS & Harvest \\
\hline $\mathrm{T}_{1}$ & 32.90 & 35.55 & 29.48 & 28.82 & 31.43 & 31.94 \\
$\mathrm{~T}_{2}$ & 7.29 & 17.93 & 34.92 & 36.00 & 36.17 & 36.50 \\
$\mathrm{~T}_{3}$ & 52.36 & 39.96 & 35.14 & 33.84 & 34.41 & 32.98 \\
$\mathrm{~T}_{4}$ & 26.90 & 34.04 & 31.95 & 35.69 & 38.05 & 41.70 \\
$\mathrm{~T}_{5}$ & 22.27 & 35.38 & 44.44 & 43.74 & 42.69 & 42.37 \\
$\mathrm{~T}_{6}$ & 33.09 & 37.25 & 46.52 & 46.51 & 47.92 & 47.42 \\
$\mathrm{~T}_{7}$ & 40.79 & 48.47 & 40.46 & 48.57 & 49.74 & 49.62 \\
$\mathrm{~T}_{8}$ & 43.73 & 53.27 & 49.71 & 53.41 & 52.96 & 52.94 \\
$\mathrm{~T}_{9}$ & 80.64 & 76.51 & 72.62 & 70.79 & 68.28 & 68.29 \\
$\mathrm{~T}_{10}$ & 100.00 & 100.00 & 100.00 & 100.00 & 100.00 & 100.00 \\
$\mathrm{~T}_{11}$ & 0.00 & 0.00 & 0.00 & 0.00 & 0.00 & 0.00 \\
\hline $\mathrm{CV}(\%)$ & 23.49 & 17.26 & 13.76 & 10.83 & 10.65 & 13.35 \\
$\mathrm{LSD}(0.05)$ & 16.00 & 12.78 & 10.34 & 8.339 & 8.271 & 10.42 \\
\hline
\end{tabular}

*Treatment details are given in materials and methods section, $\mathrm{CV}=$ Coefficient of variation LSD = Least significance difference at $5 \%$ level of significance. 
Xuan et al. [17] reported that chemicals released from allelopathic plants into the soil are toxic and caused inhibition of certain species and could be exploited as a biological tool for weed management. The sunflower cultivar is found the most effect on the target plants. Extract of sunflower at $100 \%$ concentration has been found to suppress over $80 \%$ of selected weeds indicating allelopathic properties of some sunflower cultivars can effectively be used to control noxious weed species in wheat [14].

\subsection{Effect of Sunflower Plant Extract on Crop Growth and Development}

\subsubsection{Leaf Area Index (LAI)}

LAI increased progressively from early growth stage of wheat and attained peak at around 60 DAS (booting stage) irrespective of treatments, and then declined gradually (Table 2). Weed control treatments showed significant variations in LAI. At 60 DAS, T $_{7}$ treatment (fresh SPE @ , 5t $\mathrm{ha}^{-1}$ at post-emergence) contributed to the highest LAI among the allelopathic treatments, which was statistically identical with $\mathrm{T}_{8}$ treatment (fresh SPE @ $10 \mathrm{t} \mathrm{ha}^{-1}$ at post-emergence). Data revealed that, post-emergence application of fresh sunflower plant extract@ $9 \mathrm{t} \mathrm{ha}^{-1}$ favourably influenced crop growth and development which was manifested by higher LAI in this treatment compared to other allelopathic treatments.

\subsubsection{Crop Growth Rate (CGR)}

Crop growth rate (CGR) in wheat increased progressively towards the peak between 60-75 DAT and then declined drastically, which might be due to cessation of vegetative growth and senescence of leaves [18] in a similar fashion as observed in leaf development process (Table 2). Crop growth rate depends on the amount of leaf area by the canopy and there is a functional relationship between CGR and LAI [19]. Crop growth rate of wheat at every stage was influenced by allelopathic treatments. Control treatment $\left(\mathrm{T}_{11}\right)$ showed the lowest CGR throughout the growing period, which revealed that severe weed infestation might cause lower crop growth rate. Application of SPE put significant variation in crop growth rate throughout the season (Table 3). Among the allelopathic treatments, the highest CGR $\left(28.97 \mathrm{~g} \mathrm{~m}^{-2}\right.$ day $\left.^{-1}\right)$ was found in $\mathrm{T}_{7}$ treatment (Fresh SPE @ $5 \mathrm{t} \mathrm{ha}^{-1}$ at post- emergence), even higher than that in $\mathrm{T}_{8}$ treatment (SPE $10 \mathrm{t} \mathrm{ha}^{-1}$ applied at post-emergence). Only $\mathrm{T}_{10}$ (weed free) treatment showed higher CGR (29.93 $\mathrm{g} \mathrm{m}^{-2}$ day $\left.^{-1}\right)$ over allelopathic weed control treatments at 75 DAT that was statistically similar with $\mathrm{T}_{7}$ treatment. Results indicated that, crop growth and development was higher when fresh SPE was applied@ $5 \mathrm{t}$ $\mathrm{ha}^{-1}$ at during post-emergence, while slightly slower CGR was attributed by the treatment receiving fresh SPE @ $10 \mathrm{t} \mathrm{ha}^{-1}$ during post-emergence (Table 3). Results revealed that application of fresh sunflower extract during post-emergence contributed more on the growth and development process of wheat, however, rate above $5 \mathrm{t} \mathrm{ha}^{-1}$ did not bring desired benefits in case of CGR.
Table 2. Leaf area index of wheat as influenced by sunflower plant extracts.

\begin{tabular}{llllll}
\hline \multirow{2}{*}{$\begin{array}{l}\text { Treat- } \\
\text { ment }\end{array}$} & \multicolumn{5}{l}{ Leaf Area Index (LAI) } \\
\cline { 2 - 6 } & 30 DAS & 45 DAS & 60 DAS & 75 DAS & 90 DAS \\
\hline $\mathrm{T}_{1}$ & 1.31 & 2.75 & 4.12 & 2.63 & 1.88 \\
$\mathrm{~T}_{2}$ & 1.31 & 2.94 & 4.30 & 2.76 & 2.03 \\
$\mathrm{~T}_{3}$ & 1.37 & 2.83 & 4.29 & 2.70 & 1.92 \\
$\mathrm{~T}_{4}$ & 2.04 & 3.25 & 4.88 & 3.10 & 2.15 \\
$\mathrm{~T}_{5}$ & 1.37 & 3.02 & 4.60 & 2.93 & 2.01 \\
$\mathrm{~T}_{6}$ & 1.64 & 3.17 & 4.46 & 2.79 & 1.92 \\
$\mathrm{~T}_{7}$ & 1.74 & 3.34 & 5.08 & 3.15 & 2.30 \\
$\mathrm{~T}_{8}$ & 1.61 & 3.24 & 4.97 & 2.99 & 2.17 \\
$\mathrm{~T}_{9}$ & 1.52 & 3.37 & 4.94 & 3.17 & 2.27 \\
$\mathrm{~T}_{10}$ & 1.88 & 3.43 & 5.22 & 3.31 & 2.43 \\
$\mathrm{~T}_{11}$ & 1.09 & 2.41 & 3.79 & 2.38 & 1.32 \\
\hline $\mathrm{CV}(\%)$ & 6.75 & 5.20 & 3.47 & 5.18 & 6.70 \\
\hline $\mathrm{LSD}(0.05)$ & 0.1703 & 0.2693 & 0.2693 & 0.2526 & 0.2285 \\
\hline & & & & & \\
\hline
\end{tabular}

*Treatment details are given in materials and methods section, $\mathrm{CV}=$ Coefficient of variation LSD $=$ Least significance difference at $5 \%$ level of significance.

Table 3. Crop growth rate in wheat as influenced by sunflower plant extract.

\begin{tabular}{lllll}
\hline \multirow{2}{*}{ Treatment $^{*}$} & \multicolumn{4}{l}{ Crop Growth Rate $\left(\mathbf{g ~ m}^{-\mathbf{2}} \mathbf{d a y}^{-\mathbf{1}}\right)$} \\
\cline { 2 - 5 } & $\mathbf{3 0 - 4 5}$ DAS & $\mathbf{4 5 - 6 0} \mathbf{D A S}$ & $\mathbf{6 0 - 7 5}$ DAS & $\mathbf{7 5 - 9 0 D A S}$ \\
\hline $\mathrm{T}_{1}$ & 10.33 & 18.43 & 24.95 & 5.08 \\
$\mathrm{~T}_{2}$ & 10.45 & 19.42 & 25.22 & 5.28 \\
$\mathrm{~T}_{3}$ & 11.12 & 19.09 & 28.04 & 7.10 \\
$\mathrm{~T}_{4}$ & 10.51 & 20.44 & 28.85 & 6.13 \\
$\mathrm{~T}_{5}$ & 10.89 & 21.90 & 26.52 & 6.77 \\
$\mathrm{~T}_{6}$ & 11.47 & 21.38 & 27.45 & 6.01 \\
$\mathrm{~T}_{7}$ & 11.88 & 23.88 & 28.97 & 7.07 \\
$\mathrm{~T}_{8}$ & 10.59 & 19.71 & 27.58 & 6.89 \\
$\mathrm{~T}_{9}$ & 11.75 & 22.92 & 27.59 & 7.07 \\
$\mathrm{~T}_{10}$ & 12.31 & 24.00 & 29.93 & 5.98 \\
$\mathrm{~T}_{11}$ & 10.98 & 15.62 & 21.41 & 2.55 \\
\hline $\mathrm{CV}(\%)$ & 11.36 & 7.29 & 10.25 & 47.82 \\
$\mathrm{LSD}(0.05)$ & 2.14 & 2.594 & 4.800 & 4.918 \\
\hline
\end{tabular}

* Treatment details are given in materials and methods section, $\mathrm{CV}=$ Coefficient of variation LSD $=$ Least significance difference at $5 \%$ level of significance.

\subsubsection{Total Dry Matter Production}

Total dry matter (TDM) production varied due to difference in timing, type and rate of sunflower plant extract application. Data indicated that, dose and timing of SPE application significantly influenced the production and accumulation of total dry matter. At harvest, the highest TDM of $1102.67 \mathrm{~g} \mathrm{~m}^{-2}$ was contributed by the treatment receiving fresh SPE@ $5 \mathrm{t} \mathrm{ha}^{-1}$, while the lowest $\left(1008.13 \mathrm{~g} \mathrm{~m}^{-2}\right)$ was contributed by the treatment receiving dry SPE @ $10 \mathrm{t} \mathrm{ha}^{-1}$ applied at pre-emergence (Table 4). Data indicated that, application of fresh SPE at post-emergence performed better than dry SPE applied at pre-emergence irrespective of dose. 
Table 4. Effect of SPE on total dry matter accumulation in wheat over time.

\begin{tabular}{llllcc}
\hline Treat- & \multicolumn{5}{l}{ Total Dry Matter $\left(\mathbf{g ~ m}^{-2}\right)$} \\
\cline { 2 - 6 } ment $^{*}$ & 30 DAS & 45 DAS & 60 DAS & 75 DAS & 90 DAS \\
\hline $\mathrm{T}_{1}$ & 59.00 & 217.01 & 523.53 & 950.80 & 1019.00 \\
$\mathrm{~T}_{2}$ & 56.20 & 214.38 & 535.67 & 915.80 & 1008.13 \\
$\mathrm{~T}_{3}$ & 59.47 & 226.27 & 512.67 & 903.40 & 1039.73 \\
$\mathrm{~T}_{4}$ & 78.67 & 236.27 & 512.88 & 977.00 & 1037.60 \\
$\mathrm{~T}_{5}$ & 66.40 & 229.74 & 558.20 & 979.40 & 1057.47 \\
$\mathrm{~T}_{6}$ & 68.87 & 240.97 & 561.73 & 1017.00 & 1063.67 \\
$\mathrm{~T}_{7}$ & 79.17 & 245.42 & 588.60 & 1004.80 & 1102.67 \\
$\mathrm{~T}_{8}$ & 76.95 & 234.52 & 530.20 & 901.20 & 1047.20 \\
$\mathrm{~T}_{9}$ & 74.62 & 250.90 & 594.77 & 1015.10 & 1114.63 \\
$\mathrm{~T}_{10}$ & 90.77 & 275.47 & 620.50 & 1081.10 & 1145.73 \\
$\mathrm{~T}_{11}$ & 61.44 & 226.21 & 505.53 & 913.70 & 939.93 \\
\hline $\mathrm{CV}(\%)$ & 15.29 & 7.36 & 4.47 & 3.36 & 3.48 \\
$\mathrm{LSD}(0.05)$ & 18.27 & 29.59 & 41.79 & 55.04 & 62.28 \\
\hline
\end{tabular}

*Treatment details are given in materials and methods section, $\mathrm{CV}=$ Coefficient of variation LSD $=$ Least significance difference at $5 \%$ level of significance.

\subsection{Effect of Sunflower Plant Extract on Grain Yield of Wheat}

Different weed control treatments in this experiment affected grain yield considerably (Table 5). Weed free treatment $\left(\mathrm{T}_{10}\right)$ contributed to the highest grain yield of $4.06 \mathrm{tha}^{-1}$, which might be considered as the potential yield under this study, while the lowest $\left(3.12 \mathrm{t} \mathrm{ha}^{-1}\right)$ was by control treatment $\left(\mathrm{T}_{11}\right)$. Among the allelopathic treatments, the highest grain yield of $3.91 \mathrm{t} \mathrm{ha}^{-1}$ was observed in $\mathrm{T}_{7}$ treatment (Fresh SPE @ $5 \mathrm{tha}^{-1}$ applied at post-emergence), which was also statistically identical to that (3.84 tha ${ }^{-1}$ ) in $\mathrm{T}_{8}$ treatment (Fresh SPE @ $10 \mathrm{tha}^{-1}$ applied at post-emergence) and manual weeding $\left(\mathrm{T}_{9}\right)$ treatment $\left(3.96 \mathrm{t} \mathrm{ha}^{-1}\right)$. The highest grain yield found in $\mathrm{T}_{7}$ treatment was the resultant effect of higher number of effective tillers, higher grains per spike as well as heavier grains (Table $5)$.

Data revealed that, SPE applied at post-emergence provided better wheat grain yield than when applied at pre-emergence. Again, fresh SPE application contributed to higher grain yield compared to the dried one. It might be due to that, when sunflower leaves were dried the allelopathic potential as well as nutrient releasing ability was reduced to some extent. Data on grain yield indicated that, fresh SPE @ $5 \mathrm{t} \mathrm{ha}^{-1}$ contributed to the highest grain yield of $3.91 \mathrm{t} \mathrm{ha}^{-1}$ among the allelopathic treatments, which was reduced to $3.84 \mathrm{t} \mathrm{ha}^{-1}$ when the amount of fresh SPE was raised to $10 \mathrm{tha}^{-1}$ (Table 5). Similar was the situation in case of dried SPE application at post-emergence. It might be due to the fact that, SPE at higher concentration (i.e. $10 \mathrm{tha}^{-1}$ ), besides exerting toxic effects to weeds, also exerted inhibitory effects on the growth and development of wheat plants and ultimately on yield components. The findings were in conformation with the works of the authors [20-22], who reported sunflower plants having inhibitory effects on wheat plants. In particular, Bernat et al [21] mentioned stimulatory effects of sunflower extract on wheat plants at lower concentration, whereas inhibitory effects at higher concentration. From the above results and discussion it might, therefore, reasonably be argued that sunflower plant extract, having allelopathic potential on weeds as well as wheat plants, should be used judiciously so that, better weed control efficiency as well as satisfactory wheat grain yield could be achieved. In this regard, application of fresh sunflower extract @ $5 \mathrm{t} \mathrm{ha}^{-1}$ during post-emergence might be regarded as a viable alternative to traditional weed management practices in wheat cultivation

Table 5. Yield performance of wheat as affected by sunflower plant extract.

\begin{tabular}{|c|c|c|c|c|c|c|c|}
\hline Treatment & $\begin{array}{l}\text { Effective tiller } \mathrm{m}^{-2} \\
\text { (no.) }\end{array}$ & $\begin{array}{l}\text { Spikelets spike }^{-1} \\
\text { (no.) }\end{array}$ & $\begin{array}{l}\text { Grains spike }^{-1} \\
\text { (no.) }\end{array}$ & $\begin{array}{l}\text { 1000-grain } \\
\text { weight (g) }\end{array}$ & $\begin{array}{l}\text { Grain yield } \\
\left(\mathrm{t} \mathrm{ha}^{-1}\right)\end{array}$ & $\begin{array}{l}\text { Straw yield } \\
\left(\mathrm{t} \mathrm{ha}^{-1}\right)\end{array}$ & $\begin{array}{l}\text { Harvest } \\
\text { Index }\end{array}$ \\
\hline $\mathrm{T}_{1}$ & 321 & 15.33 & 43.40 & 44.43 & 3.15 & 5.77 & 0.353 \\
\hline $\mathrm{T}_{2}$ & 330 & 16.73 & 45.57 & 44.24 & 3.55 & 6.17 & 0.365 \\
\hline $\mathrm{T}_{3}$ & 326 & 16.40 & 44.07 & 46.52 & 3.66 & 6.38 & 0.364 \\
\hline $\mathrm{T}_{4}$ & 344 & 16.27 & 44.43 & 45.69 & 3.80 & 6.58 & 0.366 \\
\hline $\mathrm{T}_{5}$ & 350 & 16.20 & 44.53 & 46.03 & 3.88 & 6.70 & 0.367 \\
\hline $\mathrm{T}_{6}$ & 333 & 16.80 & 46.27 & 44.40 & 3.73 & 6.47 & 0.366 \\
\hline $\mathrm{T}_{7}$ & 368 & 16.97 & 47.53 & 46.45 & 3.91 & 6.86 & 0.363 \\
\hline $\mathrm{T}_{8}$ & 321 & 16.60 & 46.57 & 45.53 & 3.84 & 5.60 & 0.362 \\
\hline $\mathrm{T}_{9}$ & 343 & 17.13 & 48.13 & 46.12 & 3.96 & 6.83 & 0.367 \\
\hline $\mathrm{T}_{10}$ & 350 & 17.05 & 48.72 & 46.53 & 4.06 & 7.00 & 0.368 \\
\hline $\mathrm{T}_{11}$ & 296 & 14.50 & 37.70 & 43.55 & 3.12 & 5.50 & 0.362 \\
\hline LSD & 20.11 & 1.03 & 2.507 & 0.65 & 0.15 & 0.22 & 0.08 \\
\hline CV (\%) & 3.50 & 4.39 & 3.27 & 2.40 & 2.06 & 2.04 & 5.10 \\
\hline
\end{tabular}

${ }^{*}$ Treatment details are given in materials and methods section, $\mathrm{CV}=$ Coefficient of variation LSD $=$ Least significance difference at $5 \%$ level of significance.

\section{Conclusion}

Fresh sunflower plant extracts@10 t ha ${ }^{-1}$ applied at post-emergence provided better weed control efficiency compared to pre-emergence application in wheat. On the other hand, fresh sunflower plant extracts @ $5 \mathrm{t} \mathrm{ha}^{-1}$ applied at post-emergence, contributed to satisfactory weed control effi- ciency, better crop growth and higher grain yield in wheat. Therefore, application of fresh sunflower plant extract @ $5 \mathrm{t}$ $\mathrm{ha}^{-1}$ at post-emergence might be considered as a viable alternative to traditional weed management practices. However, on-farm trials were recommended to determine the appropriate dose, application time, and method aiming at fine-tuning of the practice before farmers' adoption. 


\section{References}

[1] Hossain, A. \& Teixeira da Silva, J. A. (2013). Wheat production in Bangladesh: its future in the light of global warming. AoB PLANTS5: 1-24.

[2] Index Mundi. (2012). Bangladesh wheat production by year: market year, production (1000MT) and growth rate (\%).http://www.indexmundi.com/agriculture/?country=bd\&co mmodity=wheat\& graph=production (4 November 2012).

[3] Anonymous. (2012). Promoting adaptation of climate change in Bangladesh by Practical Action Bangladesh. practicalaction.org/media/download/5857.

[4] Turk, M. A. \& Tawaha A. R. M. (2002). Effect of sowing rates and weed control methods on winter wheat under Mediterranean environment, Pakistan J. Agron. 16 (4): 461-464.

[5] Khan, M. \& Haq, N. (2002). Wheat crop yield loss assessment due to weeds. Sarhad J. Agric. 18: 449-453.

[6] El-hamid, M. M. A., Hassanein, E. E. \& Shebl, S. M. (1998). Weed/wheat competition in Nile delta. Assinu J. Afri. Sci., 29: 105-113.

[7] Heidarzade, A, Pirdashti, H. \& Esmaeili, M. (2010). Quantification of allelopathic substances and inhibitory potential in root exudates of rice (Oryza sativa) varieties on Barnyard grass (Echinochloa crusgalli L.). Plant Omics J. 3: 204-209.

[8] Anjum. T. \& Bajwa, R. (2005). A bioactive annuionone from sunflower leaves. Phytochemistry, 66: 1919-1921.

[9] Bhadoria, P. B. S. (2011). Allelopathy a natural way towards weed management. American J. Experimental Agri.1: 7-20.

[10] Younqing, M. A. (2005). Allelopathic Studies of common wheat. Weed Biology and Management. 5: 93-104.

[11] Gao, Y., Zheng. C., Li. Y., Fan. C., Tu, G. \& Gao. J. (2008). Chemical constituents from leaves of allelopathic cultivar sunflower in China. Chem. Natu. Comp. 44 (6): 773-775.

[12] Macias, F. A., Ascension, T., Galindo, J. L. G., Rosa, M., Varela, A. J. \& Molinillo, J. M. G. (2002). Bioactive terpinoids from sunflower leaves cv. Peredovick. Phytochemistry, 61: 687-692.
[13] Awan, F. K., Rasheed M., Ashraf, M. \& Khurshid, M. Y. (2012). Efficacy of Brassica Sorghum and sunflower aqueous extracts to control wheat weeds under rainfed conditions of Pothwar, Pakistan. The Journal of Animal \& Plant Sci., 22(3): 715-721.

[14] Nikneshan, P., Karimmojeni, H., Moghanibashi, M. \& Hosseini, N. A. S. (2011). Allelopathic potential of sunflower on weed management in safflower and wheat AJCS, 5 (11): $1434-1440$.

[15] Sawant, A. C. \& Jadav S. N. (1985). Efficiency of different herbicides for weed control in transplanted rice in Konkan. Indian J. Weed Sci.17 (3): 35-39.

[16] Cheema, Z. A., Khaliq, A. \& Mubeen, M. (2003). Response of wheat and winter weeds to foliar application of different plant water extracts of sorghum (S. bicolor). Pak. J. weed Sci. Res., 9 (1-2): 89-97.

[17] Xuan, T. D., Tawata, S.,.Khanh, T. D \& Chung, I. M. (2005). Decomposition of allelopathic plants in soil. J. Agron. Crop Sci. 191 (3): 162-171.

[18] Ferdous, A. K. M. 2001. Effect of nitrogen and phosphorus fertilizer on nutrient uptake and productivity of edible poded pea. M. S. Thesis. Department of Agronomy. BSMRAU, Salna, Gazipur.

[19] Wilson, J. 1981. Analysis of growth, photosynthesis and light interception for single plants and stands. Ann. Bot., 48: 507-512.

[20] Gawronskis, W., Bernat, W. \& Gawronska, H. (2002). Allelopathic potential of sunflower mulch in weed control. Third World Congress on Allelopathy, Sato printing Co. Ltd, Tsukuba, Japan.

[21] Bernat, W., Helena, G., Janowiak, F. \& Gawronski, W. (2004). The effect of sunflower allelopathics on germination and seedling vigour of winter wheat and mustard. Department of Pomology and Basic Natural Sciences in Horticulture, Warsaw Agricultural University, Warszawa.

[22] Ghafar, A., Saleem. B. \& Qureshi, M. J. (2000). Allelopathic effects of sunflower on germination and seedling growth of wheat. Pak. J. Biol. Sci., 3 (8): 1301-1302. 